\title{
SYNTHESIS OF A NEURAL NETWORK MODEL OF INDUSTRIAL CONSTRUCTION PROCESSES USING AN INDICATOR SYSTEM
}

Leoshchenko S. D. - Post-graduate student of the Department of Software Tools, National University "Zaporizhzhia Polytechnic", Zaporizhzhia, Ukraine.

Oliinyk A. O. - Dr. Sc., Associate Professor, Professor of the Department of Software Tools, National University "Zaporizhzhia Polytechnic", Zaporizhzhia, Ukraine.

Subbotin S. A. - Dr. Sc., Professor, Head of the Department of Software Tools, National University "Zaporizhzhia Polytechnic", Zaporizhzhia, Ukraine.

Netrebko V. V. - Dr. Sc., Associate Professor, Professor of the Department of Equipment and Technology of Welding Production, National University "Zaporizhzhia Polytechnic”, Zaporizhzhia, Ukraine.

Gofman Ye. O. - PhD, Senior Researcher of the Research Unit, National University "Zaporizhzhia Polytechnic", Zaporizhzhia, Ukraine.

\begin{abstract}
Context. The problem of a neural network model synthesis for industrial processes with the definition of an optimal topology characterized by a high level of logical transparency and acceptable accuracy is considered. The object of research is the process of neural network modeling of industrial processes using an indicator system to simplify and select the topology of neuromodels..

Objective of the work is consists in synthesis a neural network model of industrial processes with a high level of logical transparency and acceptable accuracy based on the use of the system.

Method. A method is proposed to use artificial neural networks of feedforward propagation for modeling industrial processes. After evaluating the overall level of complexity of the modeling problem based on the indicator system, it was decided to build a neuromodel based on historical data. Using the characteristics of the input data of the problem, the most optimal structure of the neural network was calculated for further modeling of the system. A high level of logical transparency of neuromodels significantly expands their practical use and reduces the resource intensity of industrial processes.

Results. Neuromodels of industrial processes are obtained based on historical data. The use of an indicator system made it possible to significantly increase the level of logical transparency of models, while maintaining a high level of accuracy. Constructed neuromodels reduce the resource intensity of industrial processes by increasing the level of preliminary modeling.

Conclusions. The conducted experiments confirmed the operability of the proposed mathematical software and allow us to recommend it for use in practice in modeling industrial processes. Prospects for further research may lie in the neuroevolutionary synthesis of more complex topologies of artificial neural networks for performing multi-criteria optimization.
\end{abstract}

KEYWORDS: modeling, industrial processes, indicator system, neuromodel, sampling, training, error.

\author{
ABBREVIATIONS \\ ANN is an artificial neural net; \\ OS is organized simplicity.

\section{NOMENCLATURE} \\ $C A w P$ is complexity is associated with people; \\ Inf $_{\text {Sample }}$ is a general information of input data (data \\ $K_{\text {input }}$ is a number of element types in the neural net- \\ $K_{\text {corrY }}$ is a number of independent variables that
} set); work; strongly correlate with the original features;

$K_{i m p}$ is a number of the most significant independent variables among factors 4

$K_{\text {ntcorrX }}$ is a number of independent variables that are weakly dependent on others or do not correlate with each other4

$n$ is a number of input features that characterize sample instances;

$N_{i}$ is a multiple neurons at the network input;

$N_{i_{l}}$ is a neuron at the network input;
$N_{O}$ is a multiple neurons at the network output;

$N_{o_{p}}$ is a neuron at the network output;

$N_{h}$ is a multiple neurons of the hidden network layer;

$N_{h_{r}}$ is a hidden network layer neuron;

Num $_{\text {elemtype }}$ is a number of element types in the neural network;

$N N$ is a neural network;

$N N_{\text {struct }}$ is a structure of neural network;

$O C$ is organized complexity;

$l$ is a number of neurons at the network input;

Levaccmeas is a measurement accuracy level;

Lev $v_{c t r}$ is a level of significant and less significant and/or non-significant factors4

Lev $v_{\text {manag }}$ is a level of possible control and management;

$L e v_{\text {task }}$ is a conditional difficulty level of the task;

Lev $v_{\text {smplfctn }}$ is a level of possible simplification of the structure;

$m$ is a number of dependent (categorical) features of sample instances; 
$p$ is a number of neurons at the network output;

Param $_{T}$ is additional and specificity parameters of task;

$q$ is a number of connections between neurons in the network;

$r$ is number of neurons in the hidden network layer;

$R C$ is random complexity;

Sample is a data set;

Task is general represent of the modeling task;

$w$ is a multiple of connections between neurons;

$w_{q}$ is a connection between neurons in the network;

$x_{n}$ is a independent attribute of the sample instance;

$X$ is a set of independent attribute (variables);

$y_{m}$ is a value of the dependent variable (attribute) of the sample instance;

$Y$ is a set of values of dependent variables.

\section{INTRODUCTION}

Today, much attention in production is paid to improving equipment, but in fact, the autonomous performance of equipment and its perfection do not take into account the size of batches, the time spent on transferring parts between machines [1-4]. The most significant costs in the technological chain fall on production. Static modeling does not provide a complete answer to many questions the way out of this situation is to switch to complex (simulation modeling) production processes and create a model [1, 2].

Such a model can be investigated over time for both a single test and a given set. Usually, simulation models are built to find the optimal solution in conditions of resource constraints, when other mathematical models are too complex. Production system modeling is used when conducting experiments with a real system is impossible or impractical [3]. Simulation modeling of production processes connects all areas of product production: production process development, production process modeling and technological preparation of production, as well as production management. Based on the results of such modeling, the parameters of movement of workpieces and parts should be regulated [1-3]. The results of simulation modeling are not calculated using formulas, as is the case when using analytical models, but are a product of statistical processing of data observed and recorded during the processing of the modeling program. The simulation model, as an object of measurement, unlike real systems, is a fully accessible system.

The object of modeling can be industrial, logistics, transport, and other systems. Modeling of production systems allows to $[1-4]$ :

- identify and fix problems in advance that will manifest themselves on Ethan commissioning and would require financial and time costs;

- reduce investment in production with the same productivity parameters;
- optimize production and choose the most rational solution from a variety of options.

These advantages indicate the importance of using modeling in production and industrial processes, because it can significantly reduce costs. However, when modeling complex, nonlinear processes, systems, and objects, the question always arises as to what is best to use as the basis for the model [1]. ANN whose parametric synthesis is based on historical data about processes, objects, or systems can produce hidden knowledge from the data [4]. This makes it possible to account for implicit relationships. The logical structure of such neuromodels usually remains hidden from the user. The problem of manifestation (contrast) of this hidden logical structure is solved by reducing neural networks to a special logically transparent sparse form.

That is why the applied problem of constructing models of real industrial processes based on ANN, which would be characterized by a high level of logical transparency and acceptable accuracy of operation, is relevant.

The object of study is the process of constructing neuromodels of industrial processes with a high level of logical transparency and acceptable accuracy of operation.

Using a system of indicators, it is possible to determine the structural features of the Ann at the very beginning, which will be used as the basis of the model.

The subject of the study is a neural network model of industrial processes, which is characterized by a high level of logical transparency and acceptable accuracy.

Using information about the modeling task and evaluating the input data, it is necessary to build a neuromodel.

The purpose of the work is to construct and study neuromodels of industrial processes with a preliminary definition of structural features based on the use of a system of indicators.

\section{PROBLEM STATEMENT}

Most of the tasks associated with the synthesis of models based on data about industrial processes have a different nature and a high level of specificity $\left(\operatorname{Param}_{T}\right)$. However, when using the apparatus of neural networks, it is sufficient to have a comprehensive assessment of the complexity of the task: Task $=\left\{\right.$ Param $\left._{T}, \operatorname{LeV}_{\text {Task }}\right\}$. Such a comprehensive assessment can be obtained on the basis of information about the input data of the task (a sample of data) and a group of criteria for evaluating the accuracy of the data and the requirements for the model: $L e v_{\text {Task }}=\left\{I n f_{\text {sample }}, L e v_{\text {smplfctm }}, L e v_{\text {fctr }}, L e v_{\text {accmeas }}, L e v_{\text {manag }}\right\}$.

It was noted in [5] that a simple neuromodel based on a perceptron will be sufficient for tasks belonging to the OS category. Then such a model ( $N N$ ) will consist of: a set of neurons $N=\left\{N_{i}, N_{O}, N_{h}\right\}$ consisting of subsets of input $\quad N_{i}=\left\{N_{i_{1}}, N_{i_{2}}, \ldots, N_{i_{l}}\right\}, l=1,2, \ldots,\left|N_{i}\right|, \quad$ output $N_{o}=\left\{N_{o_{1}}, N_{O_{2}}, \ldots, N_{o_{p}}\right\}, p=1,2, \ldots,\left|N_{o}\right|$, and hidden neu- 
rons $N_{h}=\left\{N_{h_{1}}, N_{h_{2}}, \ldots, N_{h_{r}}\right\}, r=1,2, \ldots,\left|N_{h}\right|$. The number of neurons in the hidden layer $\left(N_{h}=\left\{N_{h_{1}}, N_{h_{2}}, \ldots, N_{h_{r}}\right\}\right.$, $\left.r=1,2, \ldots,\left|N_{h}\right|\right)$ can be calculated based on analytical estimates of the input data. The input data of the problem is represented by an information Sample $=\langle X, Y\rangle$, where $X=\left\{x_{1}, x_{2}, \ldots x_{n}\right\}$ is the set of independent variables: features, $Y=\left\{y_{1}, y_{2}, \ldots y_{m}\right\}$ is the set of values of dependent variables, $n$ and $m$ are the numbers of input features that characterize the sample instances.

After that, it can proceed to determining the weights of connections between neurons $w=\left\{w_{q}\right\}$, in other words, to parametric synthesis. Having determined the values of the elements of sets, we can consider the synthesis of ANN: complete.

Therefore, the first subtask will be to determine the exact category of complexity of the problem based on the values of the criteria $L e v_{\text {Task }}=\left\{\right.$ Inf $_{\text {sample }}$, Lev $v_{\text {smplfctm }}$, Lev fctr $_{\text {f }}$, Lev $_{\text {accmeas }}$, Lev $\left.v_{\text {manag }}\right\}$ and data about the data sample. The next subtask will be the calculation of the number of neurons in the hidden layer of the network $\left|N_{h}\right|=K_{\text {input }}-K_{\text {corrY }}-K_{\text {imp }}-K_{\text {ntcorrX }} \quad$ [5].

\section{REVIEW OF THE LITERATURE}

Technological processes of industrial production, especially the processes of cutting structural materials, are very complex in their physical and chemical nature [6-8]. Until now, there are no analytical models accepted by everyone that accurately describe the patterns of tool wear and load processes, thermal processes in the cutting zone, etc. Therefore, in mechanical engineering technology, models that previously designated as empirical are very often used [6, 7]. Empirical models of objects and processes are the result of processing experimental data on the behavior of an object or process using mathematical statistical analysis methods. Very often, the mathematical apparatus of regression and correlation analysis is used to build models of objects based on the results of experimental studies [7].

They studied the interdependencies of height and mass of people of different ages and were faced with the need to introduce such indicators of this dependence that would reflect the relationship between the studied characteristics of a person, but would not define each other Strictly unambiguously. Currently, regression and correlation are the main concepts of statistics [7].

The main task of correlation analysis is to identify the significance of the relationship between the values of various random variables. The relationship between quantities (including random variables) in which one value of one quantity (argument) corresponds to one or more welldefined values of another quantity is called, respectively, an unambiguous or multi-valued functional dependence. The relationship between quantities, in which each value of one quantity corresponds with the corresponding prob(C) Leoshchenko S., Oliinyk A., Subbotin S., Netrebko V., Gofman Ye., 2021 DOI 10.15588/1607-3274-2021-4-7 ability to a set of possible values of another, is called probabilistic (stochastic, statistical). Examples of correlation are the relationships between the strength and fluidity limits of steel of a certain brand, between size errors and shape errors of the part surface, between the test temperature and the strength of the material, etc. [6-8].

The mathematical apparatus of regression analysis allow to:

- evaluate unknown parameters of the regression model proposed for the study;

- check the statistical significance of model parameters;

- check the adequacy of the model;

- evaluate the accuracy of the model.

The type of regression model is proposed by the researcher himself, and he proceeds from the following:

- the physical essence of the object or phenomenon under study;

- the nature of the experimental material;

- analysis of a priori information.

The easiest object for model is an object that has one input and one output factor. The input factor characterizes the impact on the object under study. In technological processes of mechanical engineering, this can be temperature, force, time, geometric parameters of the tool, characteristics of the processed and tool materials, etc. The output factor characterizes the reaction (response) of the object to the influence of the input factor. Initial factors in technological processes of mechanical engineering - the length of the path traveled by the tool, the amount of wear, stress, the quality of the treated surface, etc.

Usually, building models and studying an object begins with the simplest models: linear ones [9-12]. The linear model corresponds to a regression curve in the form of a simple line. If we have an unlimited number of experimental points, then the linear regression model has the form [9]:

$$
y^{s}=\sum_{j=1}^{N} w_{j} x_{j}^{s}, s=1,2, \ldots, S,
$$

where $y^{s}$ is the value of the initial feature for the $s$-th instance (observation) of the sample, is the weight $w_{j}$ of $j$-th attribute, $x_{j}^{S}$ is the value of the $j$-th attribute for the $s$-th instance of the sample, $N$ is the number of features that characterize the sample instances, $S$ is the sample size.

In more complex cases, multidimensional linear regression, in addition to first-order variables, can also include variables reduced to different powers, as well as their combinations in the form of products and quotients of different orders [10-12]. In this case, each such combination or variable of some order is considered as an additional dummy variable of the first order. And regression, which essentially combines nonlinear functions, reduces to a linear weighted sum of First-Order variables. In this paper, we will use the least squares method to determine the coefficients $w=\left\{w_{j}\right\}$ for [9-12]: 
- first-order linear regression models:

$$
y=w_{0}+\sum_{j=1}^{N} w_{j} x_{j}
$$

- second-order linear regression models:

$$
y=w_{0}+\sum_{j=1}^{N} w_{j} x_{j}+\sum_{j=1}^{N} w_{(N+j)} x_{j}^{2}
$$

- second-order linear regression models with a firstorder fraction:

$$
y=w_{0}+\sum_{j=1}^{N} w_{j} x_{j}+\sum_{j=1}^{N} \sum_{p=j+1}^{N}\left(w_{N+j} \frac{x_{j}}{x_{p}}\right)+\sum_{j=1}^{N} w_{(N(0.5 N-1)+j)} x_{j}^{2} ;
$$

- linear regression polynomial models with a reduced number of features:

$$
y^{S}=\sum_{j=1}^{N} w_{j} x_{j}^{s-1}+\varepsilon_{j} .
$$

Currently, a large number of methods for constructing mathematical models of various objects are described. At the same time, among them, methods for constructing mathematical models of technological processes should be distinguished. When compiling mathematical models of technological processes, they rarely have the necessary complete a priori information about the technological object and its environment $[13,14]$. Even if there are known systems of equations describing the behavior of the system, it often turns out that there is no data on the value of individual parameters, and besides, often the existing models are too complex and the adaptation of such models becomes quite time-consuming and lengthy. In the future, it turns out that the model adopted during the design process only roughly reflects the object, which causes an error when managing using such a model. Building a meaningful analytical model of a complex object is problematic, and sometimes impossible, because. the order of the dynamical system and the presence of various nonlinearities are unknown. Therefore, it is desirable to build models of other classes.

An alternative modeling method is ANN [13, 14]. ANN is a mathematical analog of biological neurons in the brain. ANN can be considered as a directed graph with weighted connections, in which artificial neurons are nodes. These models differ in the structure of individual neurons, in the topology of connections between them, and in learning algorithms. The ANN of direct distribution has an architecture consisting of layers (Fig. 1): in such models, the input features of the recognized instance are fed to the network inputs and then propagated from the input layer $\left(x_{1} \ldots x_{n}\right)$ to the original $\left(y_{1} \ldots y_{m}\right)[13,14]$.

Each neuron on the hidden and output layers receives signals from the outputs of neurons in the previous layer at the inputs. The input vector of each neuron is converted to a scalar using a weight (discriminant) function, after which the value of the output signal is calculated using the activation function. The output values of the last layer are the result of the neural network.

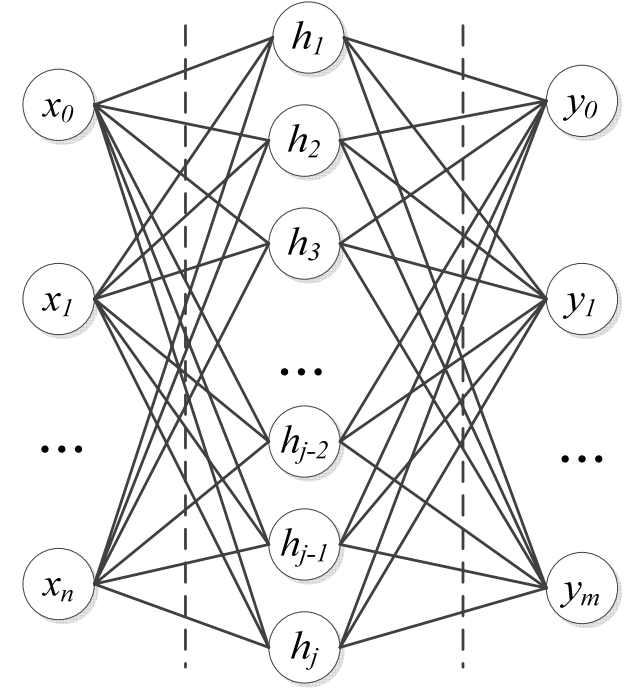

Figure 1 - Multilayer perceptron

The output values of each neuron are determined by the formula:

$$
O_{m}=\psi\left(w_{m, 0}+\sum_{n=1}^{\text {Num }_{\text {prev }}} w_{m, n} \cdot \text { Val }_{\text {outprev }}\right),
$$

where $\psi(x)$ is the activation function, $w$ the weighting factors, $\mathrm{Val}_{\text {outprev }}$ is the output values of the neurons of the previous layer, Num ${ }_{\text {prev }}$ is the number of neurons of the previous layer, $m=1.2, \ldots, M, M-$ the number of neurons in the current layer [15].

\section{MATERIALS AND METHODS}

As it was given in the previous section, the modeling task can be unified for a specific task after a certain comprehensive assessment of its complexity. Given that the structure of ANN ( $N N=$ (struct, param) ) allows to most subtly encode the relationships between the input data ( $X=\left\{x_{1}, x_{2}, \ldots x_{n}\right\}$ ), it is necessary to accurately select the synthesis option for such a non-network model. Based on the values of the indicators to assess the complexity of the task $\left(\operatorname{Lev}_{\text {Task }}=\left\{\right.\right.$ Inf $_{\text {sample }}, L e v_{\text {smplfctm }}$, Lev $v_{f c t r}$, Lev $v_{\text {accmeas }}$, $\left.L e v_{\text {manag }}\right\}$ ), it can be chosen a way to synthesize the most acceptable structure [5].

Thus, the use of recurrent neural networks can lead to a problem of retraining, when the model will show good results with a high level of accuracy on the training data, but the accuracy will immediately decrease on the test data, in other words, the model will work only on the training sample.

In the case when the model was synthesized for a large-scale sample $(n>200)$ of data, at the same time, the data was updated (new data about the object or system under study was obtained: Sample $=\left\langle X^{\mid}, Y^{\mid}\right\rangle$) or the existing data was corrected, a strategy for structural opti- 
mization of the previously synthesized ANN may be useful. With this approach, it will be important to evaluate the possibility of simplifying the model structure. Structural optimization will consist in a point-by-point change of the neuromodel: updating the activation function, removing or adding an interneuronal connection ( struct $=\left\{N^{\prime}, c^{\prime}\right\}, \quad N^{\prime}=\left\{N_{i}^{\prime}, N^{\prime}{ }_{h}, N^{\prime}{ }_{o}\right\}, \quad c^{\prime}=\left\{c^{\prime}\right\}$ ). By eliminating the connections responsible for noisy data, it is possible to significantly increase the accuracy of the resulting model. In contrast to the complete re-execution of the synthesis, this approach will differ significantly in a lower level of resource consumption [5].

In the case when a problem with input data Sample $=\langle X, Y\rangle$ that is questionable can be modeled (there is a question about the accuracy of the data, their excess or a high degree of interconnectedness), it is necessary to resort to input data preprocessing. Thus, the selection of informative features will allow us to exclude uninformative features Sample $=\left\langle X^{\mid}, Y\right\rangle$, which will subsequently increase the level of logical transparency of the neuromodel. By spending more time on data preprocessing, it is possible to significantly reduce the time resources at the stage of model synthesis based on ANN.

When modeling complex processes, objects and systems, data about which are recorded by sensor systems with high frequency and represent Big Data $(n>1000$ and real-time pre-processing is impossible). A highprecision neuromodel may be required. In this case, neu- roevolutionary approaches can be used for the synthesis of such a model, which are more capable of guaranteeing an accurate architectural architecture of ANNs with a high level of accuracy [5].

However, most industrial construction processes are not characterized by excessive data or their constantly updated nature. Therefore, such processes belong to the OS category. The measurements of most of these processes are either automated, since they are made on the basis of the readings of special sensors, or they are protected from inaccuracies, since they are made using special equipment. This way, always $L e v_{\text {accmeas }} \leq 0$. Also, most industrial construction processes are associated with fully controlled systems and objects (in most cases, the management is automated). Therefore, in this case, too, always $L e v_{\text {manag }}=0$.

The criteria characterizing the possibility of simplifying the structure and the number of significant factors also differ in small values, since they are not focused on operational processes, where there are difficult-to-fix features $\left(\right.$ Lev $_{\text {smplfctn }}=-1 ;$ Lev $\left._{f c t r}=-1\right)$ [5].

The general scheme of chosen the category of complicity using indicators prepared as a formula (7).

Therefore, we can conclude that it has a level of complexity of the OS category, which makes it possible to further use indicators to determine the structural features of the model (Fig. 2).

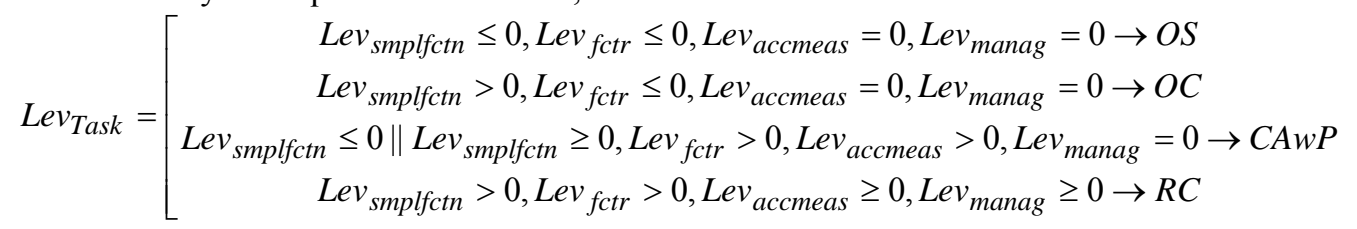

$$
\begin{aligned}
& \text { Inf } f_{\text {Sample }} \ll< \\
& L e v_{\text {smplfctn }} \leq 0 \\
& \operatorname{Lev}_{\text {fctr }} \leq 0 \\
& \text { LeV }_{\text {accmeas }}=0 \\
& \text { LeV } v_{\text {manag }}=0 \\
& \left|N_{h}\right|=K_{\text {input }}-K_{\text {corrY }}-K_{\text {imp }}-K_{\text {ntcorrX }}=3 \text {. }
\end{aligned}
$$
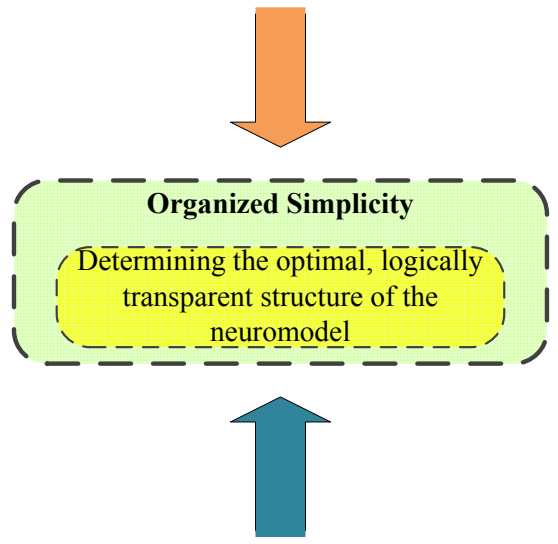

\section{EXPERIMENTS}

Figure 2 - Organized simplicity category of modeling task 
impurities. An example of data sampling is shown in Table 1 .

High-chromium cast irons with a chromium content of $10 . .35 \%$ are used for the manufacture of parts of mechanisms operating under conditions of intense abrasive wear [16]. These parts must have significant hardness. Improving the design of parts of various mechanisms (ground, slurry and sand pumps, hammer crushers, ball mills, flotation machines) requires their mechanical processing by cutting. This leads to conflicting requirements for materials, namely: maximum hardness is required to ensure wear resistance, and minimum hardness is required for cutting processing.

The solution to this problem is that the material must have satisfactory machinability by cutting in the casting state (low hardness) [17], and after mechanical processing by cutting, heat treatment must be performed [18], which will ensure a sufficient level of hardness and, accordingly, wear resistance.

Samples of high-chromium cast iron containing: $1.09 \ldots 3.54 \% \mathrm{C}, 11.26 \ldots 29.68 \% \mathrm{Cr}, 0.77 \ldots .5 .71 \% \mathrm{Mn}$, $0.13 \ldots 2.86 \% \mathrm{Ni}, 0.99 \ldots 1.46 \% \mathrm{Si}$ were manufactured. For these samples, cutter wear $\left(\mathrm{I}_{\text {cut }}\right)$ was determined during mechanical cutting. Minimal cutter wear of $0.45 \mathrm{mi}-$ crons/m was observed when cutting sample 1 with a min- imum carbon content of $1.09 \%$ and the amount of carbides $(\mathrm{K}): 9.2 \%$. The hardness of cast iron (HRC) and microhardness of the components of the base structure ( $\mathrm{HV} 50_{\text {based }}$ ) and carbides ( $\mathrm{HV} 50_{\text {car }}$ ) were determined in the casting state and after heat treatment of annealing at $690^{\circ} \mathrm{C}$ and $730^{\circ} \mathrm{C}$ for 9 hours and normalization from $1050^{\circ} \mathrm{C}$ with an exposure time of 4.5 hours.

It is necessary to establish the following functions: cutter wear $\left(\mathrm{I}_{\text {cut }}\right)$, amount of carbides $(\mathrm{K})$, hardness (HRC), microhardness of the base ( $\left.\mathrm{HV} 50_{\text {based }}\right)$ and carbides $\left(\mathrm{HV} 50_{\text {car }}\right)$ in the casting state and after heat treatment (annealing, normalization) from the arguments: content in Cast Iron C, Cr, mn, Ni, Si.

The sample consists of input and output features:

$-x_{1}$ is content in the alloy with, $\%$;

$-x_{2}$ is content of $\mathrm{Cr}$ in the alloy, \%;

$-x_{3}$ is Mn content in the alloy, $\%$;

$-x_{4}$ is $\mathrm{Ni}$ alloy content, $\%$;

$-x_{5}$ is $\mathrm{Si}$ content in the alloy, $\%$;

$-y_{1}$ is cutter wear $\left(\mathrm{I}_{\text {cut }}\right)$;

$-y_{2}$ is amount of carbides $(\mathrm{K})$;

$-y_{3}$ is hardness (HRC);

$-y_{4}$ is microhardness of the base (HV50 based);

$-y_{5}$ is microhardness of carbides ( $\mathrm{HV} 50_{\mathrm{car}}$ ).

Table 1 - General information about data set

\begin{tabular}{|c|c|c|c|c|c|c|c|c|c|}
\hline$x_{1}$ & $x_{2}$ & $x_{3}$ & $\ldots$ & $x_{18}$ & $y_{1}$ & $y_{2}$ & $y_{3}$ & $\ldots$ \\
\hline 1.09 & 17.33 & 1.99 & $\ldots$ & 1.37 & 0.45 & 9.2 & 34.1 & $\ldots$ \\
\hline 1.52 & 18.73 & 1.49 & $\ldots$ & 1.33 & 0.91 & 13.4 & 35.7 & $\ldots$ \\
\hline 2.55 & 11.91 & 3.8 & $\ldots$ & 1.26 & 9.12 & 18.7 & 38.9 & $\ldots$ \\
\hline 2.24 & 22.82 & 1.21 & $\ldots$ & 1.29 & 2.96 & 19.4 & 49.1 & $\ldots$ & $\ldots$ \\
\hline$\ldots$ & $\ldots$ & $\ldots$ & $\ldots$ & $\ldots$ & $\ldots$ & $\ldots$ & $\ldots$ & $\ldots$ & $\ldots$ \\
\hline 3.01 & 29.68 & 0.72 & $\ldots$ & 1.09 & 39.63 & 32.1 & 57.7 & $\ldots$ \\
\hline
\end{tabular}

Table 2 - Linear regression models

\begin{tabular}{|c|l|l|l|}
\hline $\begin{array}{c}\text { Dependent } \\
\text { variable } \mid\end{array}$ & \multicolumn{1}{|c|}{ Model type } & \multicolumn{1}{|c|}{$\begin{array}{c}\text { Total quadratic } \\
\text { error }\end{array}$} & Average $\left|y_{\text {rear }}-y_{\text {calc }}\right|$ \\
\hline \multirow{5}{*}{$y_{1}$} & First-order linear model (2) & 57.9872 & 4.6689 \\
\cline { 2 - 4 } & Second-order linear model (3) & 58.0843 & 1.6301 \\
\cline { 2 - 4 } & Second-order linear model with first-order fractions (4) & 1.8432 & 0.1972 \\
\cline { 2 - 4 } & $\begin{array}{l}\text { Linear regression polynomial model with a reduced number of } \\
\text { features (5) }\end{array}$ & 1.8432 & 0.1942 \\
\hline \multirow{5}{*}{$y_{2}$} & First-order linear model (2) & 52.0201 & 1.2409 \\
\cline { 2 - 4 } & Second-order linear model (3) & 28.7258 & 1.0976 \\
\cline { 2 - 4 } & Second-order linear model with first-order fractions (4) & 8.2949 & 0.2554 \\
\cline { 2 - 4 } & $\begin{array}{l}\text { Linear regression polynomial model with a reduced number of } \\
\text { features (5) }\end{array}$ & 8.2949 & 0.2223 \\
\hline \multirow{5}{*}{$y_{3}$} & First-order linear model (2) & 16.1631 & 2.7727 \\
\cline { 2 - 4 } & Second-order linear model (3) & 10.1685 & 2.0367 \\
\cline { 2 - 4 } & Second-order linear model with first-order fractions (4) & 6.3619 & 0.4485 \\
\cline { 2 - 4 } & $\begin{array}{l}\text { Linear regression polynomial model with a reduced number of } \\
\text { features (5) }\end{array}$ & 6.3619 & 0.4148 \\
\hline \multirow{5}{*}{$y_{4}$} & First-order linear model (2) & 27.3060 & 3.5000 \\
\cline { 2 - 4 } & Second-order linear model (3) & 19.8430 & 3.1000 \\
\cline { 2 - 4 } & Second-order linear model with first-order fractions (4) & 5.3524 & 0.6004 \\
\cline { 2 - 4 } & $\begin{array}{l}\text { Linear regression polynomial model with a reduced number of } \\
\text { features (5) }\end{array}$ & 5.3524 & 0.4224 \\
\hline \multirow{3}{*}{$y_{5}$} & First-order linear model (2) & 2.6163 & 1.1000 \\
\cline { 2 - 4 } & Second-order linear model (3) & 7.2305 & 3.1000 \\
\cline { 2 - 4 } & Second-order linear model with first-order fractions (4) & 9.6063 & 0.1108 \\
\cline { 2 - 4 } & $\begin{array}{l}\text { Linear regression polynomial model with a reduced number of } \\
\text { features (5) }\end{array}$ & 9.6063 & 0.1255 \\
\hline
\end{tabular}


Table 3 - Results for ANN-based models

\begin{tabular}{|c|c|c|c|}
\hline $\begin{array}{c}\text { Target } \\
\text { variable }\end{array}$ & $\begin{array}{c}\text { Number of hid- } \\
\text { den neurons }\end{array}$ & $\begin{array}{c}\text { Training } \\
\text { Time, } \mathrm{s}\end{array}$ & Average error \\
\hline$y_{1}$ & 3 & 3 & 0.061046 \\
\hline$y_{2}$ & 3 & 2 & 0.093592 \\
\hline$y_{3}$ & 3 & 4 & 0.040249 \\
\hline$y_{4}$ & 3 & 2 & 0.011954 \\
\hline$y_{5}$ & 3 & 2 & 0.096513 \\
\hline
\end{tabular}

Table 4 - Model results based on test data

\begin{tabular}{|c|c|c|c|c|c|}
\hline $\begin{array}{c}\text { Target } \\
\text { variable }\end{array}$ & $\begin{array}{c}\text { First-order linear } \\
\text { model (2) }\end{array}$ & $\begin{array}{c}\text { Second-order } \\
\text { linear model } \\
(3)\end{array}$ & $\begin{array}{c}\text { Second-order linear mod- } \\
\text { el with first-order frac- } \\
\text { tions (4) }\end{array}$ & $\begin{array}{c}\text { Linear regression poly- } \\
\text { nomial model with a } \\
\text { reduced number of fea- } \\
\text { tures }(5)\end{array}$ & 0.3 \\
\hline$y_{1}$ & 5.1 & 1.8 & 0.2 & 0.3 & 0.1 \\
\hline$y_{2}$ & 1.7 & 1.5 & 0.4 & 0.5 & 0.12 \\
\hline$y_{3}$ & 3.0 & 2.6 & 0.6 & 0.6 & 0.08 \\
\hline$y_{4}$ & 4.2 & 3.8 & 0.8 & 0.4 & 0.05 \\
\hline$y_{5}$ & 1.42 & 3.58 & 0.3 & 0.13 & \\
\hline
\end{tabular}

\section{RESULTS}

Table 2 shows the results for linear regression models. During compression special attention was concentrated on total quadratic error and average real and calculated results of depended feature.

Table 3 shows the results for ANN-based models. During compression special attention was concentrated on number of hidden neurons (what was calculated based on system of indicators), training time (calculated on seconds), average error of model.

Table 4 shows the results of models based on test data. During compression special attention was concentrated on average error of models for different depended features.

\section{DISCUSSION}

Based on the results of the initial analysis, the task was assigned to the OS group. After all, the input sample was not excessive, and the risks of human influence were excluded. The only significant complicating factor is the poorly conditioned correlation matrices.

Further calculations showed that the use of 3 neurons in the hidden layer is sufficient to build a neuromodel with acceptable accuracy of operation.

Analyzing the initial results, we should note a fairly large run-up among the model training time: from $4 \mathrm{sec}-$ onds (the largest indicator among ANN-based models) to 34.37 for linear regression models.

The results obtained on the data after reduction showed that the accuracy increased when constructing a neuromodel with a certain structure based on the indicator system, and the time significantly decreased.

Additionally, we should note the high level of logical transparency of the obtained Ann-based models.

\section{CONCLUSIONS}

The urgent scientific and applied problem of constructing a neural network model of industrial processes with a high level of logical transparency and acceptable accuracy based on the use of a system of criteria for determining the structure is solved.

The scientific novelty lies in the study of the use of a system of criteria for determining the structural features of a neural network model. Based on the assessment of the complexity of the task and the system of indicators, it was possible to obtain logically transparent neuromodels with a high level of accuracy of work.

The practical significance lies in the fact that the developed neural network models can be used during the implementation of real technical processes in production facilities. Their use will significantly reduce production costs and automate the modeling process.

Prospects for further research and development areas include the development of neuromodel synthesis methods based on the combined use of complex Ann topologies and swarm optimization methods.

\section{ACKNOWLEDGEMENTS}

The work was carried out with the support of the state The work was carried out with the support of the state budget research projects of the state budget of the National University "Zaporozhzhia Polytechnic" "Intelligent methods and software for diagnostics and non-destructive quality control of military and civilian applications" (state registration number 0119U100360) and "Development of methods and tools for analysis and prediction of dynamic behavior of nonlinear objects" (state registration number 0121U107499).

\section{REFERENCES}

1. Ameisen E. Building Machine Learning Powered Applications, Going from Idea to Product. California, O’Reilly Media, 2020, $260 \mathrm{p}$.

2. Bonaccorso G. Mastering Machine Learning Algorithms, Expert techniques to implement popular machine learning algorithms and fine-tune your models. Birmingham, Packt Publishing, $2018,576 \mathrm{p}$.

3. Patan K. Artificial Neural Networks for the Modelling and Fault Diagnosis of Technical Process. Berlin, Springer, 2008, 112 p. DOI: 10.1007/978-3-540-79872-9

4. Leoshchenko S., Oliinyk A., Subbotin S., Zaiko T. Using Modern Architectures of Recurrent Neural Networks for Technical Diagnosis of Complex Systems, 2018 International Scientific-Practical Conference Problems of Info-communications. Science and Technology (PIC S\&T), Kharkiv, 9-12 October 2018, proceedings. Kharkiv, IEEE, 2018, pp. 411-416. DOI: 10.1109/INFOCOMMST.2018.8632015

5. Leoshchenko S., Subbotin S., Oliinyk A., Narivs'kiy O. Implementation of the indicator system in modeling complex technical systems, Radio Electronics, Computer Science, Control, 
2021, Vol. 1, pp. 117-126. DOI: 10.15588/1607-3274-2021-112

6. Ahmadian A., Salahshour S. Soft Computing Approach for Mathematical Modeling of Engineering. London, Chapman and Hall (CRC Press), 2021, $222 \mathrm{p}$

7. Sayyaadi H. Modeling, Assessment, and Optimization of Energy Systems. Cambridge, Academic Press, 2020, 558 p.

8. Koulamas C., Lazarescu M. T. Real-Time Sensor Networks and Systems for the Industrial IoT. Basel, Mdpi AG, 2020, 242 p. DOI: 10.3390/books978-3-03943-431-2

9. Senge P. M. The Fifth Discipline, The Art \& Practice of The Learning Organization. New York, Doubleday, 2006, 445 p.

10. Bruce P., Bruce A. Practical Statistics for Data Scientists, 50 Essential Concepts. California, O'Reilly Media, 2017, 318 p.

11. Finch W. H. Exploratory Factor Analysis. California, SAGE Publications, 2019, 144 p.

12. Rencher A. C., Christensen W.F. Methods of Multivariate Analysis. New Jersey, John Wiley \& Sons, 2012, 800 p.

13. Dean A., Voss D., Draguljić D. Design and Analysis of Experiments (Springer Texts in Statistics), 2nd Edition. Berlin, Springer, 2017, 865 p. DOI: 10.1007/978-3-319-52250-0
14. Sewak M. Deep Reinforcement Learning, Frontiers of Artificial Intelligence. Berlin, Springer, 2020, 220 p. DOI: 10.1007/978981-13-8285-7

15. Leoshchenko S. D., Oliinyk A. O., Subbotin S. A., Gofman Ye. O., Ilyashenko M. B. Synthesis and usage of neural network models with probabilistic structure coding, Radio Electronics, Computer Science, Control, 2021, Vol. 2, P. 93-104. DOI, 10.15588/1607-3274-2021-2-10.

16. Belikov S., Volchok I., Netrebko V. Manganese influence on chromium distribution in high-chromium cast iron, Archives of Metallurgy and Materials, Vol. 58 (3), 2013, pp. 895-897. DOI: 10.2478/amm-2013-0095

17. Netrebko V.V. Influence of physical and heat processes on the structure and properties of high-chromium cast iron during machining, Science and Transport Progress, Vol. 6(54), 2014, pp. 97-103. DOI: 10.15802/stp2014/33395 [In Russian]

18. Netrebko V. V. Influence of the cast iron's chemical composition on the content of $\mathrm{cr}$ in the base after normalization from $1050^{\circ} \mathrm{C}$, Casting and Metallurgy, Vol. 1, 2018, pp. 34-40. [In Russian]

Received 10.08.2021 Accepted 25.10.2021

\section{УДК 004.896}

\section{СИНТЕЗ НЕЙРОМЕРЕЖЕВОЇ МОДЕЛІ ПРОМИСЛОВИХ ПРОЦЕСІВ БУДІВНИЦТВА 3 ВИКОРИСТАННЯМ СИСТЕМИ ІНДИКАТОРІВ}

Леощенко С. Д. - аспірант кафедри програмних засобів Національного університету «Запорізька політехніка», Запоріжжя Україна.

Олійник А. О. - д-р техн. наук, доцент, професор кафедри програмних засобів Національного університету «Запорізька політехніка», Запоріжжя, Україна.

Субботін С. О. - д-р техн. наук, професор, завідувач кафедри програмних засобів Національного університету «Запорізька політехніка», Запоріжжя, Україна.

Нетребко В. В. - д-р техн. наук, професор кафедри обладнання та технології зварювального виробництва Національного університету «Запорізька політехніка», Запоріжжя, Україна.

Гофман Є. О. - канд. техн. наук, старший науковий співробітник науково-дослідної частини Національного університету «Запорізька політехніка», Запоріжжя, Україна.

\section{АНОТАЦІЯ}

Актуальність. Розглянуто задачу побудови нейромережевої моделі промислових процесів із визначенням оптимальної топології, що відрізняється високим рівнем логічної прозорості та прийнятною точністю. Об'єктом дослідження $є$ процес нейромережевого моделювання промислових процесів із застосуванням індикаторної системи для спрощення та вибору топології нейромоделі.

Мета роботи полягає у побудові нейромережевої моделі промислових процесів з високим рівнем логічної прозорості та прийнятною точністю на основі використанні системи.

Метод. Запропоновано використовувати штучні нейронні мережі прямого поширення для моделювання промислових процесів. Після оцінки загального рівня складності задачі моделювання на основі індикаторної системи було прийнято рішення будувати нейромодель на основі історичних даних. Використовуючи характеристики вхідних даних задачі було розраховано найбільш оптимальну структуру нейронної мережі для подальшого моделювання системи. Високий рівень логічної прозорості нейромоделей, значно розширює їх практичне використання та знижує ресурсоємність промислових процесів.

Результати. Отримано нейромоделі промислових процесів на основі історичних даних. Використання індикаторної системи дозволило в значній мірі збільшити рівень логічної прозорості моделей, зберігаючи високий рівень точності. Побудовані нейромоделі знижують ресурсоємність промислових процесів за рахунок збільшення рівня попереднього моделювання.

Висновки. Проведені експерименти підтвердили працездатність запропонованого математичного забезпечення і дозволяють рекомендувати його для використання на практиці при моделюванні промислових процесів. Перспективи подальших досліджень можуть полягати нейроеволюційному синтезі більш складних топологій штучних нейронних мереж для виконання багатокритеріальної оптимізації.

КЛЮЧОВІ СЛОВА: моделювання, промислові процеси, система індикаторів, нейромодель, вибірка, навчання, помилка.

УДК 004.896

\section{СИНТЕЗ НЕЙРОСЕТЕВОЙ МОДЕЛИ ПРОМЫШЛЕННЫХ ПРОЦЕССОВ СТРОИТЕЛЬСТВА С} ИСПОЛЬЗОВАНИЕМ СИСТЕМЫ ИНДИКАТОРОВ

Леощенко С. Д. - аспирант кафедры программных средств Национального университета «Запорожская политехника», Запорожье Украина.

(C) Leoshchenko S., Oliinyk A., Subbotin S., Netrebko V., Gofman Ye., 2021

DOI 10.15588/1607-3274-2021-4-7 
Олейник А. А. - д-р техн. наук, доцент, профессор кафедры программных средств Национального университета «Запорожская Политехника», Запорожье Украина.

Субботин С. А. - д-р техн. наук, профессор, заведующий кафедрой программных средств Национального университета «Запорожская политехника», Запорожье Украина.

Нетребко В. В. - д-р техн. наук, профессор кафедры оборудования и технологии сварочного производства Национального университета «Запорожская политехника», Запорожье Украина.

Гофман Е. А. - старший научный сотрудник научно-исследовательской части Национального университета «Запорожская политехника», Запорожье Украина.

\section{АННОТАЦИЯ}

Актуальность. Рассмотрена задача построения нейросетевой модели промышленных процессов с определением оптимальной топологии, которая отличается высоким уровнем логической прозрачности и приемлемой точностью. Объектом исследования является процесс нейросетевого моделирования промышленных строительных процессов с применением индикаторной системы для упрощения выбора топологии нейромоделей.

Цель работы заключается в построении нейросетевой модели промышленных строительных процессов с высоким уровнем логической прозрачности и приемлемой точностью на основе использовании системы.

Метод. Предложено использовать искусственные нейронные сети прямого распространения для моделирования промышленных процессов. После оценки общего уровня сложности задачи моделирования на основе индикаторной системы было принято решение строить нейромодель на основе исторических данных. Используя характеристики входных данных задачи была рассчитана наиболее оптимальная структура нейронной сети для дальнейшего моделирования системы. Высокий уровень логической прозрачности нейромоделей, значительно расширяет их практическое использование и снижает ресурсоемкость промышленных процессов.

Результаты. Получены нейромодели промышленных процессов на основе исторических данных. Использование индикаторной системы позволило в значительной степени увеличить уровень логической прозрачности моделей, сохраняя высокий уровень точности. Построены нейромоделей снижают ресурсоемкость промышленных процессов за счет увеличения уровня предыдущего моделирования.

Выводы. Проведенные эксперименты подтвердили работоспособность предложенного математического обеспечения и позволяют рекомендовать его для использования на практике при моделировании промышленных процессов. Перспективы дальнейших исследований могут заключаться в нейроэволюционном синтезе более сложных топологий искусственных нейронных сетей для выполнения многокритериальной оптимизации.

КЛЮЧЕВЫЕ СЛОВА: моделирование, промышленные процессы, система индикаторов, нейромодель, выборка, обучение, ошибка.

\section{ЛІТЕРАТУРА / ЛИТЕРАТУРА}

1. Ameisen E. Building Machine Learning Powered Applications: Going from Idea to Product / E. Ameisen. - California: O'Reilly Media, 2020. $-260 \mathrm{p}$

2. Bonaccorso G. Mastering Machine Learning Algorithms: Expert techniques to implement popular machine learning algorithms and fine-tune your models / G. Bonaccorso. - Birmingham: Packt Publishing, 2018. - 576 p

3. Patan K. Artificial Neural Networks for the Modelling and Fault Diagnosis of Technical Processe / K. Patan. - Berlin: Springer, 2008. - 112 p. DOI: 10.1007/978-3-540-79872-9

4. Using Modern Architectures of Recurrent Neural Net-works for Technical Diagnosis of Complex Systems / [S. Leoshchenko, A. Oliinyk, S. Subbotin, T. Zaiko] // 2018 International Scientific-Practical Conference Problems of Infocommunications. Science and Technology (PIC S\&T), Kharkiv, 9-12 October 2018 : proceedings. - Kharkiv: IEEE, 2018. - P. 411-416. DOI 10.1109/INFOCOMMST.2018.8632015

5. Implementation of the indicator system in modeling complex technical systems / [S. Leoshchenko, S. Subbotin, A. Oliinyk, O. Narivs'kiy] // Radio Electronics, Computer Science, Control. - 2021. - Vol. 1. - P. 117-126. DOI: 10.15588/1607-32742021-1-12

6. Ahmadian A. Soft Computing Approach for Mathematical Modeling of Engineering / A. Ahmadian, S. Salahshour. - London : Chapman and Hall (CRC Press), 2021. - 222 p.

7. Sayyaadi H. Modeling, Assessment, and Optimization of Energy Systems / H. Sayyaadi. - Cambridge : Academic Press, 2020. $-558 \mathrm{p}$.

8. Koulamas C. Real-Time Sensor Networks and Systems for the Industrial IoT / C. Koulamas, M. T Lazarescu. - Basel : Mdpi AG, 2020. - 242 p. DOI: 10.3390/books978-3-03943-431-2

9. Senge P. M. The Fifth Discipline: The Art \& Practice of The Learning Organization / P. M. Senge. - New York : Doubleday, 2006. $-445 \mathrm{p}$

(C) Leoshchenko S., Oliinyk A., Subbotin S., Netrebko V., Gofman Ye., 2021 DOI 10.15588/1607-3274-2021-4-7
10. Bruce P. Practical Statistics for Data Scientists: 50 Essential Concepts / P. Bruce, A. Bruce. - California : O'Reilly Media, 2017. $-318 \mathrm{p}$.

11. Finch W. H. Exploratory Factor Analysis: 1st Edition W. Holmes Finch. - California: SAGE Publications, 2019. $144 \mathrm{p}$.

12. Rencher A. C. Methods of Multivariate Analysis / A C. Rencher, W. F. Christensen. - New Jersey : John Wiley \& Sons, 2012. $-800 \mathrm{p}$.

13. Dean A. Design and Analysis of Experiments (Springer Texts in Statistics) / A. Dean, D. Voss, D. Draguljić. - Berlin : Springer, 2017. - 865 p. DOI: 10.1007/978-3-319-52250-0

14. Sewak M. Deep Reinforcement Learning: Frontiers of Artificial Intelligence / M. Sewak. - Berlin: Springer, 2020 - 220 p. DOI: 10.1007/978-981-13-8285-7

15. Synthesis and usage of neural network models with probabilistic structure coding / [S. D. Leoshchenko, A. O. Oliinyk , S. A. Subbotin et al.] // Radio Electronics, Computer Science, Control. - 2021. - Vol. 2. - P. 93-104. DOI: 10.15588/16073274-2021-2-10

16. Belikov S. Manganese influence on chromium distribution in high-chromium cast iron / S. Belikov, I. Volchok, V. Netrebko // Archives of Metallurgy and Materials. - Vol. 58 (3) - 2013. P. 895-897. DOI:10.2478/amm-2013-0095

17. Нетребко В. В. Влияние физических и тепловых процессов на структуру и свойства высокохромистого чугуна при обработке резанием / В. В. Нетребко // Наука та прогрес транспорту. Вісник Дніпропетровського національного університету залізничного транспорту: науковий журнал. №6 (54). - 2014. - C. 97-103. DOI: 10.15802/stp2014/33395

18. Нетребко В.В. Влияние химического состава чугуна на содержание $\mathrm{Cr}$ в основе после нормализации от $1050^{\circ} \mathrm{C} /$ В. В. Нетребко, І. П. Волчок // Литье и Металлургия. № 1. -2018 . - С. 34-40. 